\title{
IMPLEMENTATION OF ECONOMIC DEMOCRACY PRINCIPLE IN ISLAMIC BANKING POLICIES THROUGH FINANCIAL SERVICES AUTHORITY (FSA) IN INDONESIA
}

\author{
Yusup Hidayat \\ Lecturer at Law Faculty of Al Azhar Indonesia University (S3 UIN Jakarta) \\ e-Mail: yusup@uai.ac.id \\ Fokky Fuad \\ Lecturer at Law Faculty of Al Azhar Indonesia University ( S3 Indonesia University), \\ Maslihati Nurhidayati \\ Lecturer at Law Faculty of Al Azhar University ( S2 Indonesia University, Now student of S3 Law \\ Program at Indonesia University)
}

\begin{abstract}
The enactment of Law No. 21 Year 2011 on the Financial Services Authority (FSA) made the regulation and supervision of financial institutions both banks and nonbank be integrated, including the regulation and supervision of sharia financial institutions in which there is sharia Islamic Banking. One of the principles of Islamic banking, as stated in Law No. 21 of 2008 concerning Islamic Banking is the Principle of Economic Democracy. In the implementation of the principle of economic democracy that the FSA has a significant role in pushing the Islamic banking institution to utilize its resources to promote the local economy, especially groups of people whose economic access is still minimal. In 2014, the FSA issued Regulation No. 19 in relation to inclusive finance. In these regulations, the FSA encourages banking institutions to provide banking services to people who have been marginalized through the branchless bank program. This POJK applies to both conventional banking and Islamic banking. Some conventional banks have been undertaking this program with a wide range of dynamics. Some Islamic banks have been also undertaking it, while others are still at the preparation stage. This paper will analyze the regulations issued by the FSA in order to encourage Islamic banking institutions in actualizing the principle of economic democracy, especially in relation to inclusive finance program. The research method used in this article is normative juridical with the support of primary source through the FSA.
\end{abstract}

\begin{abstract}
Abstrak: Berlakunya Undang-Undang Nomor 21 Tabun 2011 tentang Otoritas Jasa Kenangan (OJK) menjadikan pengaturan dan pengawasan Lembaga Keuangan baik. Bank maupun Nonbank menjadi terintegrasi, termasuk. pengaturan dan pengawasan Lembaga keuangan syariah yang di dalamnya terdapat Perbankan Syariah. Salah satu asas Perbankan syariah sebagaimana tertuang dalam Undang-Undang No. 21 tabun 2008 tentang Perbankan Syariah adalah Asas Demokrasi Ekonomi. Dalam implementasi asas demokrasi ekonomi tersebut OJK memiliki peran signifikan dalam mendorong lembaga perbankan syariah untuk. mendayagunakan sumber daya yang dimiliki untuk memajukan ekonomi masyarakat terutama kelompok masyarakat yang secara akses ekonomi masib minim. Pada tahun 2014 OJK mengeluarkan Peraturan OJK No 19 terkait dengan keuangan Inkusif. Dalam peraturan tersebut OJK mendorong lembaga perbankan untuk memberikan layanan jasa perbankan kepada masyarakat yang selama ini termarginalkan melalui program Laku Pandai. POJK ini berlaku baik untuk perbankan konvensional maupun perbankan syariah. Beberapa bank konvensional sudah meakukan program ini dengan berbagai macam dinamikanya. Sementara itu bank syariah juga sebagian ada yang sudah menjalankan sementara yang lain masih pada tahap persiapan. Tulisan ini akan menganalisis peraturanperaturan yang dikeluarkan OJK dalam mendorong lembaga perbankan syariah dalam menujudkan asas demokrasi ekonomi terutama terkait dengan program keuangan inklusif. Metode penelitian pada penelitian adalah yuridis normatif dengan dukungan data-data primer melalui pihak OJK.
\end{abstract}

Keywords: Banking service, economic, financial, democracy.

\section{Preliminary}

One of the principles of Islamic banking is the principle of economic democracy. God's law does not distinguish between rich and poor, and it does not distinguish between black and white too. ${ }^{1}$ As in conventional banking, Islamic banking is expected to provide equal access to all levels of society, whether the people who are economically benefited and having an easy access to banking institutions, or the people who are economically facing difficulties and having limited access to banking institutions.

\footnotetext{
${ }^{1}$ M. Syafi'i Antonio, Bank Syariab: dari Teori ke Praktik. (Jakarta: Gema Insani, 2009), 14.
} 
As a business organization, the Islamic banking is profit oriented and so the conventional banking, both are further strengthened in Act Number 10 of 1998 on Banking. For its future growth, the Islamic banking has to make product innovations which are socially acceptable and make also a large profit. But on the other hand, the Islamic banking should also observe the Islamic principles as guidance in conducting its business activities. Another aspect to note is the real sectors of economic activity of society. As the spirit contained in the Holy Qoran states "In order not to be concentrated among the rich only". The current world economic inequality is quite alarming that only 1 percent of the population controls more than half the world economy. The rest is contested by $99 \%$ of the world's population. This figure is based on the study report conducted by nonprofit organizations, Oxfam. ${ }^{2}$

The Islamic banking is required to be able to realize its ideals magnitude to encourage the real sector to move quickly. Islamic banks do not recognize the term interest. Islamic banks apply the principle of Profit-sharing. 3 This shows that Islamic banks more emphasize the real business and not speculation. For that purpose, its involvement in financing small businesses is crucial. Indonesian Bank which was then under the Act No. 21 Year 2011 as the regulator and then moves to the Financial Services Authority (FSA) should certainly encourage the existing Islamic banking to ensure active participation in promoting small businesses. How big the FSA's commitment to encourage Islamic banking institutions in promoting the economy through small businesses can be seen from the products of the regulations concerned with it.

This study will identify the rules of the Financial Services Authority (FSA) in relation to the implementation of the principles of economic democracy, as mandated in the Constitution of 1945 and the Islamic Banking Act itself. Furthermore, this study will analyze the substance of the rules of the FSA.

The tendency of business institutions to get profit from its business processes is a character and instinct of the existence of its institutions, including the Islamic banking institution. However, the laws governing Islamic banking stressed the need for the

\footnotetext{
${ }^{2}$ Doli D Siregar, Mukhlisin, and Suharto, Redistribusi Aset dan Ekonomi Kerakyatan (Jakarta: Sinergi Manajemen Aset dan Yayasan Pendidikan Penilai Indonesia, 2016), 5.

${ }^{3}$ Kasmir, Bank dan Lembaga Keuangan Lainnya (Jakarta: Raja Grafindo Persada, 2014), 169.
}

involvement of Islamic banking in motivating the economy in the country through the financing of the real sector that were evenly distributed. It means that Islamic banking is not only concentrating on big business institutions with billions of rupiah but also in the small business institutions, which is during the 1998 economic crisis can actually stand.

As regulator, the FSA is expected to be a driving force and a controller of Islamic banking in carrying out its mission to boost the State's economy through the financing of the real sector. This study will look at how the FSA issue policies relating to Islamic banking's commitment to small businesses and whether such policies provide a forced power to the business of Islamic banking to orient its business to small entrepreneurs.

This study will specifically focus on the FSA policy related to inclusive finance as a policy that is claimed to be the most concerning with the lower classes of society, especially in the countryside.

Financial Inclusion Agenda is solely made to improve people's ability to manage risk, manage money in order to be consumed later in the day to cme, until it finally be able to produce something useful for the people in the vicinity. ${ }^{4}$ According to the view of sharia, Islamic financial inclusion is defined as an effort to increase community access to Islamic financial institutions so that people are able to manage and distribute financial resources in accordance with Islamic principles. ${ }^{5}$ Islamic financial inclusion acts as a means to encourage people to engage more in Islamic financial practices.

Research that are specifically related to the study of the democratic principles of Islamic banking through Bank of Indonesia policies as well as FSA, no one has done. There are several studies concerning either BI policies or the FSA, but they are unrelated to the issue of the implementation of democratic principles through regulations of Indonesian bank. Sulasih conducted a study on the influence of Bank Indonesia's policy towards the development of Islamic banking in Indonesia. She said that with the issuance of the three laws related to banking and Islamic banking namely Law No. 7 of 1992, Law No. 10 of 1998 and Law No. 21 of 2008 concerning Islamic banking institution, the Islamic banking is increasingly making progress.

\footnotetext{
${ }^{4}$ Irfan Syauqi Beik and Laily Dwi Arsyianti, Ekonomi Pembangunan Syariah. (Jakarta: Raja Grafindo Persada, 2016), 221.

${ }^{5}$ Ibid.
} 
The progress indicator is visible from spreading offices channeling and also from financial indicators that include the assets, third party funds, and financing. ${ }^{6}$

Megawati conducted a study on the implications of the Bank of Indonesia regulations towards pawn of gold in Islamic banking. The result of the study showed that Indonesia Central Bank regulation on syariah pawn made markets of sharia pawn in Islamic banking to be blocked. ${ }^{7}$

Atik Rosyadah (2011) conducted a study on Bank Indonesia's policy towards foreign investment. Bank Indonesia's policy on foreign investment has not been encouraging foreign ownership in Islamic banking in Indonesia. Of the 10 Islamic banks in Indonesia, Bank Muamalat Indonesia only is dominated by foreign share, that is Islamic Development Bank by $32,82 \%$ of the total foreign capital as much as $82,69 \% .8$

Hasbi Hasan (2012) studied the effectiveness of the supervision of the Financial Services Authority on Islamic Financial Institutions. According to Hasbi, effectiveness of the FSA supervision against Islamic banking is largely determined by how the communication and coordination of the FSA with agencies related to the Syariah banking. Among the efforts to facilitate communication and coordination between the FSA with DSN and DPS is to conduct Islamic banking unit or directorate within the organizational structure of the FSA. ${ }^{9}$

Irfan Syauqi Beik and Laily Dwi Arsyianti (2016) examined the Syariah Financial Inclusion. Financial inclusion program is basically intended to serve people who are in the bottom of the pyramid composition of the population with the lowest incomes, living in the rural area, people with special needs, employer which does not have official documents and rural population (Bank Indonesia, 2015)..$^{10}$ While the targets of the Islamic financial education are: First is the youth, the second is those who are buying a house for the first time, the third is low-income of households, and the fourth are woman, and the others are the prospective retirees and employees. ${ }^{11}$

\footnotetext{
${ }^{6}$ Sulasih, "Analisis Pengaruh Kebijakan Bank Indonesia Terhadap Perkembangan Perbankan Syariah Di Indonesia" (Universitas Muhammadiyah Yogyakarta, 2009).

7 Megawati, "Implikasi Peraturan Bank Indonesia Terhadap Praktik Gadai Emas Syariah Di Bank UDA" (Universitas Indonesia, 2012).

${ }^{8}$ Atik Rosyadah, "Kebijakan Bank Indonesia Terhadap Investasi Modal Asing Di Perbankan Syariah" (UIN Syarif Hidayatullah, 2011).
}

Research on the implementation of the principle of democracy through a policy of Bank Indonesia (FSA) has not been discussed specifically. Thus it can be said that this research is a new research related to the principle of democracy through the policies of the Financial Services Authority.

This study aims to provide an assessment on the FSA policies related to participation of Islamic Banking in financing or driving the economy. As a regulator, the FSA has a very strategic role in encouraging actors of Islamic banking to engage actively in promoting the economy of Indonesia through the financing of the real sector among small and medium entrepreneurs.

In academic perspective, this research is expected to provide benefits in criticizing the policies of Financial Services Authority related to regulating financial institutions so as to actualize finance which is does not pay attention only to the people who have access to financial institutions but also to the entire community, especially people who have been marginalized, and majority of them are in rural.

In practical terms, this reseacrh is expected to become input for both practitioners of Islamic banking and society considerably concerning the policies of the FSA on financial services oriented to the public interest, especially small business community or rural communities.

This study is a normative juridical research where researcher uses main legal materials which are regulations issued by the Financial Services Authority, whether it is in the shape of Regulation Financial Services Authority, or the Financial Services Authority Circular. Besides, the researcher is also trying to get confirmation from the FSA relating to the policies issued.

To get the main and primary legal materials, the researcher conducted the literature research, while to get support from field data, the researcher conducted interviews. Meanwhile in the analysis stage, legal materials or other supporting data is processed and then be analyzed qualitatively to explore the problems studied.

${ }^{9}$ Hasbi Hasan, "Efektivitas Pengawasan Otoritas Jasa Keuangan Terhadap Lembaga Perbankan Syariah (Effective Control of Financial Services Authority on Sharia Banking Institutions)," Jurnal Legislasi Indonesia 9, no. 3 (2012): 373.

${ }^{10}$ Beik and Laily Dwi Arsyianti, Ekonomi Pembangunan Syariah., 220.

11 Ibid., 226-227. 
The theory used in this research is the legal political theory. According to Abdul Hakim GN, the legal politic is a legal policy that will be or have been implemented nationally by the Government of Indonesia that include: firstly, the development of laws that contains construction and renewal of the material laws in order to conform with the requirements; secondly, the implementation of the provisions of existing laws, including the assignment of functions of institutions and law enforcement training. ${ }^{12}$ The definition, according to Mahfud MD showed political law, covering the construction process and the implementation of the law that can indicate the nature and to which direction the law will be constructed and enforced..$^{13}$ The birth of the FSA as a product of legislation which in this case is the Law No. 21 of 2011 and its policy relating to Conduct Smart program showed that to where the legal policies issued by the FSA is directed.

The stages of this research were done by starting with the study of the literature on Islamic banking and system of legislation, and it was conducted to obtain a more comprehensive picture about the philosophy and regulation of Islamic banking in Indonesia. The study of economic democracy is also a focus of concern in this literature study which was intended to obtain a proper theoretical framework in analyzing the issue of democracy principles in Islamic banking. Furthermore, the literature study was to identify the regulations of the Financial Services Authority relating to the implementation of the principles of economic democracy in Islamic banking.

Once the regulations of the Financial Services Authority identified, it was followed by an exhaustive review of these regulations starting from factors or the background of the issuance of these rules and then continued with the substance of the legislation itself. In the next stage, it was synchronized between the regulations with other regulations to have equality either philosophically or regulatory material itself.

To confirm these regulations, it is necessary to do interviews with the FSA to have information in the implementation on the ground.

Furthermore, after the two forms of research data are collected, then data processing is done in accordance with the proportion of each. Once the data is processed analysis is done in-depth in the

\footnotetext{
12 Moh. Mahfud MD, Politik Hukum di Indonesia (Jakarta: LP3S, 1998), 9.

13 Ibid.
}

qualitative nature of the data to get the answers to the problems studied.

\section{Research Result}

Act Number 3 of 2004 concerning amendments to the Act Number 23 of 1999 concerning Bank Indonesia mandated the establishment of independent banking supervisory agency. Article 34 of Law No. 3 of 2004 states: (1) The task of supervising the banks will be carried out by supervision institutions of independent financial sector, and established by law. (2) Establishment of a supervisory agency referred to in paragraph (1) will be implemented no later than December 31, 2010.

Philosophically, the Financial Services Authority was formed with the aim that the overall activities of financial services in the financial services sector are held regularly, fairly, transparent, and accountable and capable of realizing the system to grow in a sustainable and stable, and capable of protecting the interests of consumers and society. Financial Services Authority was formed and based on the principles of good governance, which includes the independence, accountability, responsibility, transparency, and fairness. ${ }^{14}$ Seen from this philosophical foundation that the FSA could encourage the birth of financial service institutions and become strong and healthy institution and trusted by the people and is not vulnerable to the crisis.

From the perspective of the sociological, the FSA which has the role of regulation and supervision should be directed to create efficiency, and healthy competition. Thus the principle of equality, regulation and supervision which is based on the principles of fairness and transparency should be implemented in such a way as to create an activity and economic transactions orderly, efficient and productive, and ensure the protection of customers and society. The FSA should be able to put himself in proportion and protect the interests of industry and other stakeholders..$^{15}$ Thus the FSA should be able to accommodate the aspirations of the financial institutions, either the conventional system or that uses a system based on the principles of sharia.

The FSA is the independent State institutions. FSA was established which is based on Act No. 21 of 2011. As the independent state

\footnotetext{
14 Hermansyah, Hukum Perbankan Nasional Indonesia (Jakarta: Kencana, 2008), 220

15 Ibid.
} 
institutions, the FSA has a significant authority in carrying out its duties and functions.

Implementation of the principle of independence as contained in the Act of FSA is something very crucial. Results of research done in the whole world including in the United States by James R. Bath and his colleagues said that there is no institution independent of the political influence of short-term and independent from the interests and influence of financial institutions. ${ }^{16}$

One of the indicators of the FSA independence can be seen from the structure of the Board of Commissioners. The FSA is led by the Board of Commissioners. The Board of Commissioners consists of nine (9) members as determined by the President. The Board of Commissioners is collective collegial. In the explanation of FSA's Law, it is mentioned that collective decision imply that any decision of the Board of is decided jointly by the Member of the Board of Commissioners. While the meaning of the collegial decision is that every making decision of the Board of Commissioners is based on consultation and consensus with equality and kinship between the members of the Board of Commissioners.

Board of Commissioners is the supreme leader of the FSA. In making cooperation with the authorities of supervisory agencies of financial institutions in other countries and international organizations and other international institutions in the financial services sector, members of the Board of Commissioners act as an official representing the country.

Article 5 of the FSA's Law states "the FSA has function to implemnet system of regulation and supervision which is integrated to the whole activity in the financial services sector." Then, in Article 6 of the Act states that "the FSA conduct regulation and supervision duties to:

a. Financial service activities in the banking sector.

b. Financial service activities in the capital markets sector, and

c. Financial service activities in the insurance sector, Pension Funds, Financing Institutions, and other Financial Service Institutions.

The birth of the FSA can not be separated from the spirit of the Indonesian people to realize a prosperous Indonesia as mandated in opening of

${ }^{16}$ Zulkarnain Sitompul, "Konsepsi Dan Transformasi Otoritas Jasa Keuangan (Conception and the Constitution of 1945. In general explanations, the Act FSA stated:

".....as well as provide welfare equitably to all the people of Indonesia, so the national economic development program should be implemented in a comprehensive and capable of motivating the national economic activity that has a broad reach and touch the real sector of the economy of Indonesian society. National economic development programs should also be implemented in a transparency and accountable which are guided by the principle of economic democracy as mandated by Pancasila and the Constitution of the Republic of Indonesia Year 1945. "

In 2014 the Financial Services Authority issued a very important policy related to the interests of Indonesian people, especially people who are economically facing difficulties in gaining access to financial institutions. The policy is contained in the Financial Services Authority Regulation No. 19 / POJK-03/2014 on the Financial Services without Office (Laku Pandai) in the framework of Inclusive Finance. As a continuation of the policy POJK, the FSA also issued Circular Letter No. 6 / SEOJK 03/2015 concerning Financial Services without office (Laku Pandai) in the frame of Inclusive Finance by Banks.

With the birth of the POJK, it is expected that rural communities would be avoided from the practice of money lender which is very detrimental to the community with a very high interest charges.

Two years prior to the issuance of the POJK concerning Financial Inkusif, the government launched the National Strategy programs for Inclusive Finance (SNKI). One of these programs is branchless banking or banking services without having to do in the office of a bank. Laku Pandai is part of branchless banking which were intensively conducted by the FSA since March 26, 2015.

SNKI was born as a response to the fact that Indonesia is among countries with a high level of excclusive finance. The data shows that $35 \%$ of respondents who have a bank account (LD-FEUI), $32 \%$ of the adult population that has not saved (World Bank 2012), 20\% of the adult population of Indonesia who have an account in formal financial institutions (World Bank). In order to promote inclusive finance in Indonesia, it is to choose a comprehensive manner by formulating a national strategy, prepared jointly by Bank Indonesia, the Office of the Vice President and Financial

Transformation Financial Services Authority)," Jurnal Legislasi Indonesia 9, no. 3 (2012): 347. 
ministery which is called by the National Strategy for Inclusive Finance. Then it is made 6 (six) pillars of the National Strategy on Inclusive Financial comprising as follow; 1. Financial Education, 2. Public Finance Facility, 3. Financial Information Mapping, 4. Regulatory support, 5. Facilities of intermediation and distribution channels, 6 . Consumer Protection. ${ }^{17}$

Financial inclusion or inclusive finance has an important role and become one of the pillars supporting economic growth. ${ }^{18}$ People who have been untouched by the financial institution, under the rules of the FSA it is granted access and services to empower financial institutions and avoided from practices of money lender which is very detrimental to them. In Article 1 (5) POJK No. 19 / POJK$03 / 2014$ it is mentioned that inclusive finance is a state where all people can reach easily access of financial services and have a culture to optimize the use of financial services.

According to an Economist, Firmanzah, the branchless banking program can be a balancing of the banking plan that will increase the revenuebased services (fee based income). Because according to Firmanzah, in this service 19 percent is cheaper than conventional bank services. In his view the bankings will greatly reduce operating costs, especially in serving the middle and lower class customers. Thus there be a mutually beneficial or symbiotic relationship between bankings and customers which are lower class society economically. ${ }^{19}$ In a larger context there is a process of democratization in economic matters.

In accordance with Law No. 21 Year 2011 on the Financial Services Authority, the Financial Services Authority has three tasks; they are to regulate, supervise and protect. Based on these tasks, the FSA has a great responsibility to encourage economic growth. One of the functions of law is social engineering. So the policies issued by the FSA must be able to engineer the economy, especially to people who are marginalized in terms of access to financial institutions.

Based on the results of the National Survey concerning the Indonesian financial literacy in 2013, the literacy rate of Indonesian society is very low, amounting to 21.80 percent. Meanwhile Indonesia's financial community inclusion rate

${ }^{17}$ Ahmadi Yusuf Perdana, "Deterimanan Kepemilikan Rekening Perbankan Di Indonesia (Pendekatan Ekonometrika)" (Universitas Airlangga, 2016).

18 Pavel Bosák, "Paleokarst of the Bohemian Massif in the Czech Republic: Short Review = Paleokras Češkega Masiva (Češka Republika): Kratek Pregled,” Proceedings of amounted to 59.74 percent. From these survey results can be illustrated that the Indonesian people are still many who are not familiar with financial services institutions, especially in using the products or services financial services. Based on the results of studies done by various parties, the higher level of financial literacy and financial inclusion of a society, the higher level of social welfare. ${ }^{20}$ Financial inclusion policies initiated by the FSA, it is certainly expected to increase the quantity and quality of Indonesian society literacy affecting the welfare of Indonesian people, especially the target of the policy is people who have been marginalized.

One of the inclusive finance program is branchless banking or banking services without having to do in the office of a bank (Laku Pandai). Laku Pandai is part of branchless banking, which have been intensively conducted by the FSA since March 26, 2015. Based on Article 1 paragraph (3) it is stated that the Laku Pandai is the activity of providing banking services and or other financial services that are not conducted through a network of offices, but with the cooperation with other parts and it needs to be supported by the use of information technology infrastructure.

Eko Ariantoro said that the basis of consideration of publishing Intelligent Behavior POJK is backgrounded by being still many members of the public who do not know, use and or obtain banking services and other financial services. In addition to it, the FSA, the banking industry and financial industry be committed to realize inclusive finances in line with the national strategy for Inclusive Finance (SNKI) through the Laku Pandai program or branchless banking. Therefore, the Laku Pandai provides financial product which is easy and accessible, simple, and suitable with the needs of society. ${ }^{21}$

Every financial services institutions can be host of the Laku Pandai. Article 3 (2) states that financial service institutions that can apply to be the organizer of Laku Pandai is (a) a bank, (b) an insurance company, or Islamic insurance company, and (c) Financial Services Institution other than those referred to in (a) and (b).

Products that can be provided by theFinancial Services Institution that organizes Laku Pandai are among others: 1. Savings, 2. Credit

International Symposium Man on Karst, Postojna, September 23 - 25, 199324 (1995): 109-121.

${ }^{19}$ Ibid.

20 Ibid.

${ }^{21}$ Eko Ariantoro, "Direktur Direktorat Pengembangan Inklusi Keuangan,” September 15, 2016. 
or financing for micro customer, 3. Microinsurance, and or other financial products based on the approval of the Financial Services Authority.

In Article 10 of POJK associated with Bank Operator of the Laku Pandai, it is determined that the bank that will apply for approval to host the Laku Pandai as referred to in Article 3 should comply with the requirements; a. Indonesian legal entity, b. Having rank of the risk profile, the level of operational risk and compliance risk by rankings 1, 2 or rankings 3, c. Having a network of offices in Eastern Indonesia and or the province of East Nusa Tenggara, and d. Having had a supporting infrastructure for providing electronic transaction services for bank customers including: 1. Short Message Service (SMS) banking or mobile banking, and 2. Internet banking or host to host. However, in the next paragraph states that the FSA can do periodical evaluations related to the requirements of the region of offices network in Eastern Indonesia region and or the province of East Nusa Tenggara.

Beside that, in Article 13 states that commercial banks based on business activities (BUKU) 1 and BPR or BPRS having met the requirements to become a bank organizer as referred to in Article 10 paragraph (1) letter a, b, and c can apply to organize internet banking in order to obtain approval to become a bank Operator of Laku Pandai.

In the implementation on the field in accordance with Article 16 POJK, the organizer bank of Laku Pandai in cooperation with agents to provide banking products for people who unserved by bank office networks. Agent meant here is the individual agent, and or incorporated agent. Agents are those who serve the customers and/or prospective customers in accordance with the scope of services specified in the coopration agreement.

Based on some provisions of the POJK Laku Pandai, there is no significant separation between the Bank with the conventional system and bank with sharia system. Thus this POJK applies to both conventional banking and Islamic banking. According to Eko Ariantoro, Director of the Directorate for Development of Financial Inclusion FSA said that based on POJK and SE OJK 6/2015 both conventional banks and Islamic banks can be Laku Pandai which based on the FSA approval. ${ }^{22}$ If the Islamic Banking want to conduct the Intelligent behavior, it must meet the

\footnotetext{
22 Ibid.
}

requirements as other banks do, namely; incorporated in Indonesia, having a risk profile as required, having a network of offices in Eastern Indonesia Region and or East Nusa Tenggara, having products and activities SMS of banking/mobile banking and internet banking / host to host, and has been approved by the FSA. ${ }^{23}$

Then on February 6, 2015 the Circular Letter No. 6 / SEOJK.03 / 2015 was published. The circular consists of eight main points relating to the General Provisions, Savings With Characteristics of Basic Savings Account (BSA), Submission of Application for Implementation of Practice Laku Pandai, Practicing Terms of Bank Operator of Laku Pandai, Implementation Partnership of the Laku Pandai, Information Technology, Education and Customer Protection, and reporting Implementation of Laku Pandai.

In issues of information technology, the SE FSA determine that the bank organizers ensure the readiness of information technology infrastructure and other supporting infrastructures, among others, include the availability; the application system used by agents, data center, disaster recovery center and transaction processing based on technology for the implementation of the Laku Pandai in the territory of Indonesia, information technology capable of processing and recording in real time to the customer's account at the Bank Operator, the mechanism for addressing problems occurred in the application system used in electronic devices in agent location, such as notification of error messages, as well as 10 other points.

Related to Education and Customer Protection, the SE FSA determine that the bank organizers and/or agent must implement education for customers and/or community, among others; a. benefits, risks, and costs of products of Laku Pandai, b. Procedures for the use of electronic devices or instruments to be used by customers to conduct financial transactions in order to reduce potential losses due to operational risk, c. The procedures to be observed by customer, d. The procedures for the identification of agents, e. The procedure for blocking and / or replacement of the account number under certain conditions, $f$. Prudent financial management, g. The procedure for accessing the complaints service (call center) and / or submission of complaints to the Bank Operator.

\footnotetext{
${ }^{23}$ Eko Ariantoro, "Direktur Direktorat Pengembangan Inklusi Keuangan.”
} 
The FSA Circular Letter No. 6 Year 2015 does not distinguish between conventional banking and Islamic banking. Both the banking systems was encouraged by the FSA to be involved in the implementation of inclusive finance in the form of the Laku Pandai. Banks that can qualify to become organizer of the Intelligent behavior of both conventional and Islamic bank can immediately run the Laku Pandai program.

The Intelligent behavior program is a banking service through a bank agent in the rural areas that are not covered by the Bank's office. The first banks engaged in as program organizer of the Laku Pandai is Bank Rakyat Indonesia, Bank Mandiri, BTPN, and Bank Central Asia. Until the year 2015 there were 27 commercial banks that have released the products of the Laku Pandai with 60.805 agents, among them are 59.354 of individual agents and 1.451 are in the form of incorporated agents, and have succeeded to capture 1,216,952 customers and have obtained the amount of $\mathrm{Rp}$ 67.6 billion from the third party fund. In the year 2016, the FSA have targeted the funds with amount of 2.6 trillion collected from the the Intelligent behavior. While the number of targeted agents is 167,524 agents. ${ }^{24} 25$

In monitoring and evaluation of the FSA there are some obstacles in the implementation of the Intelligent behavior program from the group of agents, namely; funding liquidity, the absence of implementation standardized modules for the Intelligent behavior by agents, the lack of the level of public confidence in the agent, limitness of knowledge and skills of agents in operating the infrastructure of the Intelligent behavior, the introduction/ publications more massive on the Intelligent behavior program be still required, including the understanding of the differences with LKD where currently be initiated by Bank of Indonesia. This is to anticipate that it is not impossible for an agent to be able to implement/act as organizers of the two programs intended simultaneously. ${ }^{26}$

Based on the data owned by the FSA, the question of the Laku Pandai policy is on the equitable implementation of the intelligent behavior between Java and non-Java. The majority of Intelligent behavior looks scattered in Java $(76.14 \%)$. While about 12 percent were located in Sumatra. Meanwhile in the eastern region of

\footnotetext{
${ }^{24}$ Bosák, "Paleokarst of the Bohemian Massif in the Czech Republic."
}

Indonesia, the percentage is very small which is only 12 percent, comprising five percent in Sulawesi, three percent in Kalimantan, two percent in Nusa Tenggara, and two percent in Bali. ${ }^{27}$

The gap of the existence of the Laku Pandai between Java and non Java showed that the Laku Pandai policies have not become effective, considering the basis or the background of forming the Laku Pandai is that as many as 183 districts out of 410 districts / cities are left behind or disadvantaged and are mostly located in the eastern region.

The problem is in POJK Article 25 paragraph (1) states that the organizer bank of the Laku Pandai can only cooperate with agents based on locations in the same city or district with the location of the bank office networks. Then in the same paragraph (2) the article states that "In the case of offices network of Bank organizers of the Laku Pandai is not available in the city or district where the position of the candidate agent, the Bank can work with prospective agents as long as: (a) there is a bank office networks of the organizer bank of the Laku Pandai in the city or district that borders with the location of the candidate agent; or (b) there is office networks of organizer bank of the Laku pandai in the city or other districts that are different from the location of the prospective agents and employees of the bank office is still able to carry out monitoring and controlling directly and (c) at the location of the position of the candidate agent, there is no the adequate financial service. Thus there is a need for POJK regulation adjustments with the objective conditions that occur in the field with looking at the issuance of POJK concerning the Laku Pandai.

The problems that emerged later also is inclusive financial policy that more focusing on large banking institutions where many involved are the banks in category of BUKU III and BUKU IV. While the institutions already living in the community have not been involved with the maximum, like Cooperatives and Islamic microfinance institutions (BMT). The policy could threaten the existence of financial institutions nonbank that has already existed with economic practical considerations. The involvement of institutions that already existed seems necessary to be considered, remembering the sizable role in pushing economic growth among the bottom

\footnotetext{
${ }^{26}$ Eko Ariantoro, "Direktur Direktorat Pengembangan Inklusi Keuangan."

${ }^{27}$ Bosák, "Paleokarst of the Bohemian Massif in the Czech Republic."
} 
circles and can maintain social stability that have been already conducive.

\section{Conclusion}

Based on the research result, it can be concluded that Financial Services Authority have been set specifically the policies relating to the implementation of the principle of economic democracy in Islamic banking with the issuance POJK No. 19 / POJK-03/2014, followed by the FSA Circular Letter No. 6/SEOJK.03/2015 on Financial Services Without Office in the Context of the Inclusive Finance. The FSA and SE POJK involve not only conventional banking in the implementation of theLaku Pandai but also Islamic banking of both Islamic banks and Islamic Public Financing Bank (BPRS). However, specific rules relating to the implementation of the Laku Pandai for Islamic banking are still undiscovered

POJK and SE FSA of the Laku pandai encourage both conventional banking and Islamic banking to conduct an inclusive financial services to the public especially marginalized communities economically. But the rquirement to become executing bank of the Laku Pandai is not easy, especially in relation to infrastructure aspects.

Constraints faced the Laku Pandai agent based on the results of the FSA monitoring are among them; funding liquidity, being no standard module for implementing the Laku Pandai by agents, the lack of the public confidence rank upon the agent, limitness of knowledge and skills of agents in operating of the infrastructure of the Laku Pandai, and being still required the introduction / publications more massive on the Laku Pandai program includes understanding the differences with LKD that currently being initiated by BI. This is meant to anticipate that it is not impossible that an agent can implement / act as organizers of the two programs simultaneously.

\section{Suggestion}

Based on the temporary result of this research, it is advisable for the FSA to review the setting of an agent for the Laku Pandai that allows areas having no bank branches of branchless bank organizer. This is to realize the goal of the inclusive financial policy itself.

The next suggestion is the need for policies that encourage cooperation between financial banking institutions with micro-finance institutions that has grown and developed in the community so that the Branchless bank program does not cause disastrous for micro-finance institutions.

\section{Bibliography}

Ahmadi Yusuf Perdana. "Deterimanan Kepemilikan Rekening Perbankan Di Indonesia (Pendekatan Ekonometrika).” Universitas Airlangga, 2016.

Antonio, M. Syafi'i. Bank Syariab: dari Teori ke Praktik. Jakarta: Gema Insani, 2009.

Beik, Irfan Syauqi, and Laily Dwi Arsyianti. Ekonomi Pembangunan Syariah. Jakarta: Raja Grafindo Persada, 2016.

Bosák, Pavel. "Paleokarst of the Bohemian Massif in the Czech Republic: Short Review = Paleokras Češkega Masiva (Češka Republika): Kratek Pregled." Proceedings of International Symposium Man on Karst, Postojna, September 23 - 25, 199324 (1995): 109-121.

Eko Ariantoro. "Direktur Direktorat Pengembangan Inklusi Keuangan," September 15, 2016.

Hasan, Hasbi. "Efektivitas Pengawasan Otoritas Jasa Keuangan Terhadap Lembaga Perbankan Syariah (Effective Control of Financial Services Authority on Sharia Banking Institutions)." Jurnal Legislasi Indonesia 9, no. 3 (2012).

Hermansyah. Hukum Perbankan Nasional Indonesia. Jakarta: Kencana, 2008.

Kasmir. Bank dan Lembaga Kenangan Lainnya. Jakarta: Raja Grafindo Persada, 2014.

MD, Moh. Mahfud. Politik Hukum di Indonesia. Jakarta: LP3S, 1998.

Megawati. "Implikasi Peraturan Bank Indonesia Terhadap Praktik Gadai Emas Syariah Di Bank UDA.” Universitas Indonesia, 2012.

Rosyadah, Atik. "Kebijakan Bank Indonesia Terhadap Investasi Modal Asing Di Perbankan Syariah." UIN Syarif Hidayatullah, 2011.

Siregar, Doli D, Mukhlisin, and Suharto. Redistribusi Aset dan Ekonomi Kerakyatan. Jakarta: Sinergi Manajemen Aset dan Yayasan Pendidikan Penilai Indonesia, 2016.

Sitompul, Zulkarnain. "Konsepsi Dan Transformasi Otoritas Jasa Keuangan (Conception and Transformation Financial Services Authority)." Jurnal Legislasi Indonesia 9, no. 3 (2012).

Sulasih. "Analisis Pengaruh Kebijakan Bank Indonesia Terhadap Perkembangan Perbankan Syariah Di Indonesia." Universitas Muhammadiyah Yogyakarta, 2009. 